\title{
30. 腹壁ヘルニアが高頻度にみられるスンクスについて
}

\author{
橋本良造 ${ }^{1)}$ 織田銑 一”鬼頭 純 三” \\ 名古屋大学 環境医学研究所 ${ }^{12}$, 同 医学部付属動物実験施設 ${ }^{2)}$
}

スンクス1)は食虫目トガリネズミ科ジネズミ亜科ジ ヤコウネズミ属に分類される哺乳類でわが国を北限と して南アジアに広く野生集団が分布している.

われわれは地域野生集団を起源とするラインやミュ ータント采など，いくつかのスンクス繁殖集団を育成 中であるが，今回これらのラインのうちでも長崎産由 来の NAG ラインに腹壁ヘルニアが比較的高頻度に発 症していることを見いだした。

NAG ラインのスンクスは長崎県長崎市茂木町にて 1973 年に採集されたものが起源となっており，現在 名古屋大学環境医学研究所, 医学部動物実験施設, 農 学部に㧊いて繁殖集団が維持されている.

前二者の繁殖集団についてこの数年間の腹壁へルニ アの発症頻度を調査したところ, 環境医学研究所で 6.9\%，医学部動物実験施設で $1.0 \%$ であった．雌に 圧倒的に多く発症し雄に発症することは稀であった (288 匹中 1 匹).

片親にヘルニアを認めた場合, 両親ともへルニアを 認めない場合にくらべ，観察離乳仔にへルニア発症を 認めることが多かった１例のみで観察数は少ない が, 両親ともへルニアを認めた場合その仔にへルニア を認めなかった. ヘルニアの遺伝的分析は今後観察数 を増やし検討する必要がある.

ヘルニアを認める母獣は仔の育成率が低くまた妊娠 率が低く、リッターサイズも小さい傾向がみられた。

解剖所見では，両側の腹直筋の間が非常に広く開大 しており，腹直筋等の腹壁を構成する筋肉が量的に少 ない状態であった。これらの所見は外観状へルニアを 呈さないNAG ラインのスンクスについてもいえた. ヘルニアは白線上に発生し, ヘルニア襄は腹膜であり ヘルニア内容は腸管でへルニア被膜のうちの腹直筋前
䩗は稀にヘルニア部に間隙を認めた。臍部は正常でへ ルニア門は白線であった.

ヒトにおいて腹壁へルニアは前腹壁および側腹壁よ り脱出するへルニアから鼠径ヘルニフ臍へルニアを除 いたものを一般に総称するものとして定義されてい $ろ^{22}$. 具体的には白線ヘルニア, 腹直筋離開, 側腹壁へ ルニア，腹壁般痕へルニアなどがあげられる．今回の NAG ラインにおけるスンクスの腹壁ヘルニアは上記 のヒトの腹壁へルニアのらち, 白線ヘルニア, 腹直筋

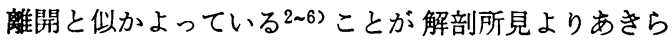
かとなった．とくに腹直筋離開とよく似ており腹直筋 離開の発生機序を研究するらえでNAG ラインのスン クスは有用ではないかと考えている.

文献

1）織田銑一，鬼頭純三，太田克明，磯村源蔵： スンクス, 学会出版センター, 東京 (1985)

2）澤口重徳：標準外科学 第 3 版（相馬 智, 武藤輝一編)，医学書院，東京，pp. 427-440 (1984)

3）安田崒生, 西村秀雄, 江崎研一郎, 山村英樹： 現代科学大系, 奇型 I 第 1 刷（木本誠二 編), 中山書店, 東京, pp. 159-191 (1974)

4) Moore, K.L.: The Developing Human Clinically Oriented Embryology 4 ed., W.B. Saunders Company, Philadelphia, pp. 159169 (1988)

5) England, M.A.: A Colour Atlas of Life before Birth, 1 ed., Wolfe Medical Publications Ltd., Netherlands, p. 122 (1983)

6) Shaw, A. and Schuster, S.R. : Pediatric Surgery, 4 ed. (Welch, K.J., Randolph, J.G., Ravitch, M.M., O'Neill, J.A.Jr. and Rowe, M.I., eds.) Year Book Medical Publishers, Inc., Chicago, pp. 731-800 (1986) 